\title{
Do Security Analysts Herd on Stock Recommendations and Does It
}

\section{Affect Returns?}

\author{
Tsai-hui Lin ${ }^{1}$, Woan-yuh Jang ${ }^{2}$ \& Seng-su Tsang ${ }^{3}$ \\ ${ }^{1}$ Department of Marketing Management, Takming University of Science and Technology, Taipei, Taiwan \\ ${ }^{2}$ Graduate Institute of Finance, National Taiwan University of Science and Technology, Taipei, Taiwan \\ ${ }^{3}$ Department of Business Administration, National Taiwan University of Science and Technology, Taipei, \\ Taiwan
}

Correspondence: Tsai-hui Lin, Department of Marketing Management, Takming University of Science and Technology, No. 56, Section 1, Huanshan Road, Taipei, Taiwan, R.O.C. Tel: 886-2-2658-5801 ext. 2724. E-mail: thlin@takming.edu.tw

Received: March 29, 2013

Accepted: April 27, $2013 \quad$ Online Published: May 21, 2013

doi:10.5539/ijef.v5n6p67

URL: http://dx.doi.org/10.5539/ijef.v5n6p67

\begin{abstract}
This study explores the herding behavior of security analysts, the firm characteristics in attracting herding, and the consequences of the herding recommendations on returns in China's stock market. By applying the LSV method, the stock recommendations of analysts are partitioned into buy- and sell-recommendations. The results show that the herding level of sell-recommendation is greater than that of buy-recommendation, which is particularly evident in the bear market. Moreover, investors selling the holdings that analysts herd to recommend "sell" might help avoid losses in the bear market. Notably, when in the bull market, if analysts herd to make sell-recommendations, investors might gain more by acting conversely. These performance variations according to market sentiments appear to be partially explained by a firm's characteristics based on additional regression analyses and are partially attributed to analysts' individual attitudes toward market sentiments.
\end{abstract}

Keywords: analysts herding, China's stock market, LSV, stock recommendation, stock return

\section{Introduction}

Herding behavior is common in the natural world. For instance, oceanic fishes with no defenses to ward off enemies strengthen their momenta by flocking together to avoid attacks. Herding may also reduce information searching cost. Following the bellwethers, for instance, saves the effort of searching for food. Mankind is not immune to this natural tendency in most instances. From the social psychological perspective, people instinctively seek security when making decisions under conditions of uncertainty. Herding behavior reflects the need for support that justifies decision-making. Stock investment involves decision-making under conditions of high uncertainty, which not surprisingly accrues herding behavior (Camerer, 1989; Daniel and Titman, 1999). For investors, herding may deviate investor's judgment from rational to emotional, which is not conducive to investment performance (Baker and Nofsinger, 2002). In financial markets, investors rushing to invest in the same assets according to a consensus influence the price and volatility of these assets. In severe cases, herding might contribute to the exuberance of a speculative market bubble. Therefore, the herding behavior of security market participants and the effects of herding on the market pricing mechanism are crucial topics.

Numerous studies have investigated the herding propensity of investors. Because investors may rely on analysts to acquire and interpret needed information for investment decision-makings, analysts if are also subjected to herding behavior may dim their reliabilities. China's stock market has benefited from economic growth and governmental encouragement. Although China is an emerging market, it has become the second largest stock market in the world. The size of the securities industry has expanded rapidly over the past decade, and the number of analysts is also increasing considerably. The top-rated analysts (literally, "gold-medal analysts") determined by institutional investors could guarantee high salaries in the past. However, in the 2012 bear market, based on a report by Sina Finance (Note 1), approximately $80 \%$ of the "valuable" stocks strongly recommended for purchase by security analysts declined in price, and over $60 \%$ of these stocks demonstrated lower performance than the Shanghai Stock Exchange composite index. Stocks that are preferred by more analysts may 
exhibit inferior performance, whereas stocks that are recommended by fewer analysts may demonstrate superior performance.

The statistics demonstrated above indicate that the herding behavior of analysts in a bear market may negatively influence the performance of recommended stocks, which further causes investors to doubt the value of professional analysis performed by analysts. Therefore, this study investigates whether the herding level of analysts when making recommendations in China's stock market affects stock prices and whether a bear/bull market can affect research results. In addition, by assuming that the herding behavior or level of analysts is correlated to subsequent stock returns, this study determines whether accessible financial and market data could be further explored to understand the characteristics of stocks recommended by herding analysts, thereby providing a reference for investment in stocks.

By investigating listed companies in the Shanghai and Shenzhen Stock Exchanges from April 2002 to September 2009, this study adopts the measure developed by Lakonishok, Shleife and Vishny, (1992) (hereafter referred to as "LSV") to examine the herding behavior of analysts according to market sentiments. Thus, the original sample was divided into two sub-samples for analyses: the recommendations of buying stocks (hereafter, "buy-herding") and the recommendations of selling stocks (hereafter, "sell-herding").

The disposition effect (Shefrin and Statman, 1985) indicates that investors often sell their winner stocks too early and hold loser stocks too long. Inspired by the disposition effect for the asymmetric behavior of investors, we wonder that investors may tend to sell their winners too early in the bull market and are reluctant to sell poorly performing stocks to realize their loss in the bear market. This study thus also tests whether or not analysts herd differently in upward and downward markets. The results show that the magnitude of sell-herding recommendations is substantially higher than that of buy-herding. By examining further the stock returns associated with the recommendations, we find that the correlations are nonlinear. Sell-herding recommendations help investors avoid losses in the bear market, but fail in the bull market. By contrast, buy-herding recommendations help investors gain in the bull market, but cause losses in the bear market. Notably, when in the bull market, if analysts herd to make sell-recommendations, investors might gain more by acting conversely.

Regarding the firm characteristics that induce analysts to engage in herding, our results show that buy-herding (sell-herding) is often bestowed on larger (smaller) firms, better (worse) operating performance, less (more) non-operating income, lower (higher) market-to-book ratio, higher (lower) asset growth rate and lower (higher) trading volume. Analysts particularly favor firms largely owned by institutional investors. However, analysts tend to herd because of making sell (buy) recommendations regarding a stock when institutional investors increase (decrease) their holdings on the stock. Furthermore, analysts herd frequently to issue sell recommendations for previous under-performed stocks and newly listed firms.

The remainder of this paper is organized as follows. Section 2 reviews the literature on herd behavior in stock markets. Section 3 describes the sample selection procedures and our research methodology. Empirical results are presented in Section 4. Finally, Section 5 summarizes our findings and presents a discussion on some of their implications.

\section{Literature Review}

This paper reviews literature from three perspectives. First, do analysts herd on their stock recommendations, and what factors motivate the herding? Second, this paper reports the measures for herding behavior. Finally, this paper presents the results of examining the associations of analyst recommendations with stock returns.

\subsection{Analyst Herding}

Several motives for the herding behavior of investors have been investigated in previous studies. For instance, investors may receive similar information, adopt same analytical tools, or have similar preferences; therefore, they prefer or avoid holding stocks with certain firm characteristics and act in the same direction (buy or sell a stock). It has been shown that institutional investors may share the same aversion toward stocks with lower liquidity or those that are less risky as a result of behaving similarly (Wermers, 1999). Other information-related causes have also been proposed, including attempting to preserve reputation (Scharfstein and Stein, 1990; Banerjee, 1992; Prendergast and Stole, 1996; Welch, 1992, 2000; Graham, 1999), information cascade (Welch, 1992; Banerjee, 1992; Bikhchandani et al., 1992), compensation-based herding (Trueman, 1994), career concerns (Scharfstein and Stein, 1990; Trueman, 1994; Prendergast and Stole, 1996), momentum or positive feedback trading (Lakonisshok et. al., 1992), and irrational psychological factors regarding window-dressing strategies (Lakonisshok et. al., 1991). Considering such viewpoints facilitates exploring the herding behavior of analyst recommendations. 
Analysts' compensations are often paid by the institutes they serve. Therefore, the monetary incentives serve natural motives for the consulting behavior of analysts. In practice, analysts in brokerage houses are hired to compose reports that arouse the interests of customers (i.e., investors), with the goal of generating increased trade volume (Hong and Kubik, 2003) or obtaining affiliated underwriting businesses (Lin and McNichols, 1998; Michaely and Womack, 1999; O'Brien et al., 2005). When offering investment advice, analysts might devote themselves to providing higher "perceived value" to their institutes than to general investors. In other words, the accuracy or independence of recommendations may not be the sole concern.

Security analysts are considered specialists in financial markets. To stand out and build consumer awareness, some analysts inevitably boast by exaggerating their differences. Thus, analysts may "anti-herd" or issue forecasts far different from the consensus (Zitzewtiz, 2001; Bernhardt et al., 2006; Naujoks et al., 2007). Furthermore, analysts with lower capability (Trueman, 1994) or high market reputations (Graham, 1999) are also documented to be keen on herding to protect their market status as well as compensations. Less experienced analysts are particularly inclined to issue bold forecasts deviating from the market consensus (Hong et al., 2000; Clement and Tse, 2005; Clarke and Subramanianb, 2006). Clarke and Subramanianb (2006) further found a U-shaped relationship between the forecasting boldness of analysts and forecasting performance, which was attributed to the convexity of analyst payoff structures in perceived ability, reputation, and employment risk.

Another source of herding is driven by firm-specific characteristics. The extent of firm diversification, for instance, may result in complex organizational structures, and consequently become less transparent while exhibiting more agency problems and information asymmetry. Consequently, firm diversification creates more hindrance and cost when performing analysis. Herding, therefore, is more pronounced among analysts concentrating on diversified companies (Kim and Pantzalis, 2003).

Finally, analyst herding may be associated with market conditions. Scharfstein and Stein (1990) indicated that herding behavior in financial markets is sometimes because of little or no information. Graham (1999) further argued that analyst herding occurs when public information is widely inconsistent with an analyst's private information. It is also a common belief that herding behavior is more prevalent when the market fluctuates to a great extent. For instance, Welch (2000) found that the influence of the prevailing consensus among analysts is greater in the bull markets. In summary, although the aforementioned studies have offered a set of mixed conclusions regarding the existence of analyst herding, this herding phenomenon has not been investigated by examining the characteristics of stock recommendations - either to buy or sell—made by analysts with respect to market sentiments.

\subsection{Measures of Herding}

Exploring the herding characteristics of buy and sell recommendations made by analysts requires using herding measures that can properly indicate the extent of buy- versus sell-herding. To investigate herding behaviors, Welch (2000) developed a complex dynamic model to measure the herding propensity of analysts. Later, Christie, and Huang (1995) and Chang et al. (2000) have used stock return dispersion to propose herding measures called the "CSSD" and "CSAD" models, respectively. Although modifications of the two measures are available (e.g., Hwang and Salmon, 2004; Gleason et al., 2004; Chiang and Zheng, 2010), for their restriction on a single market, neither can be modified to incorporate the buy-herding or sell-herding to meet the requirement of the present study.

Lakonishok et al. (1992) (LSV) used trading volume (buy and sell) to investigate whether fund managers tend to stand on the same side of the market, for a given stock and in a particular quarter. When half of the fund managers increase their holdings of one stock while the other half cut their holdings, the LSV concludes that there is no herding on the stock. By contrast, if a disproportionate number of fund managers are buying (or selling) a stock, for instance, $70 \%$ of the fund managers decrease their holdings and the remaining $30 \%$ increase holdings, then the LSV would conclude that there is herding on the stock. LSV has been broadly applied to investigate herding behavior of mutual fund managers and individual investors (Grinblatt et al., 1995; Wermers, 1999). Brown et al. (2009) extended the LSV method by dividing herding behaviors into buy-herding and sell-herding to examine whether fund managers follow the recommended revisions made by analysts. In light of the partition feature in LSV model, the present study chose to adopt this model for the measurement of analyst herding.

\subsection{Analyst Recommendation and Subsequent Stock Return}

Do investors gain by following the investment recommendations made by analysts? Numerous studies have sought to answer this question (Womack, 1996; Barber et al., 2001; Jegadeesh et al., 2004). A recent study by Wang et al. (2006) showed that, in China, stock market investors purchasing stocks with the most favorable 
consensus recommendations may yield $23.28 \%$ of abnormal returns, and selling short is the least favorable consensus recommendation to yield negative returns. In other words, the recommendations made by stock analysts affect followers' returns. In extending this line of study, the present study is also motivated to examine the subsequent performance caused by herding recommendations.

\section{Methodology}

\subsection{Data Sources}

The sample consists of the public firms included in the I/B/E/S database during the period of April 2002 through September 2009 in China. It covers both the A-shares and B-shares listed in the Shanghai and Shenzhen Stock Exchanges, excluding firms of the financial industry (banks, insurance, brokerage, etc.); firms with missing values are deleted. The information regarding a firm's market price, stock turnover, and accounting variables were collected from the Taiwan Economic Journal (TEJ) data bank. Per ownership and ownership percentage changes of institutional investors were due on the WIND database.

The sampling period covers 90 calendar months in total, yielding 29,529 observations. Table 1 shows the sample profiles by year. The means of recommendations per month range from a low of 52.1 in 2002 to a high of 735.1 in 2009 .

Table 1. Distribution of sample firms across years

\begin{tabular}{llrc}
\hline Year & No. of recommendations & \% of total & Monthly average no. of recommendations \\
\hline $2002 *$ & 469 & 1.59 & 52.1 \\
2003 & 790 & 2.68 & 65.8 \\
2004 & 1,235 & 4.18 & 102.9 \\
2005 & 2,944 & 9.97 & 245.3 \\
2006 & 4,162 & 14.09 & 346.8 \\
2007 & 5,824 & 19.72 & 485.3 \\
2008 & 7,489 & 25.36 & 624.1 \\
$2009 *$ & 6,616 & 22.41 & 735.1 \\
Total & 29,529 & 100.00 & 328.1 \\
\hline
\end{tabular}

Note: * indicates only 9 months included in a year.

\subsection{Herding Measure}

Based on relevant literature, "analyst herding" in this study is defined as a group of security analysts following each other to recommend their clients to buy (or sell) the same stock over a short horizon, such as within one month. Analysts herding to recommend buying the same stocks is called "buy-herding;" the opposite is called "sell-herding."

Security analysts are generally considered over-optimistic in making investment recommendations. Although, in practice, security analysts have five distinct recommendation levels (strong buy, buy, hold, sell, and strong sell) at their disposal, they are generally reluctant to issue the latter two negative ratings (Barber et al., 2001). Lin and McNichols (1998) remark that market react negatively to a "hold" recommendation. Accordingly, the "hold" recommendations are classified into the "sell side" group, and result in two groups: namely, buy-side and sell-side recommendations. The division, therefore, is applicable in using the LSV model as follows:

Given a stock $i$ during month $t$, the herding $H M_{i t}$ is:

$$
\left.H M \quad \text { it }=\left|P_{i t}-E\left[P_{i t}\right]\right|-E\left[\mid P_{i t}-E\left[P_{i t}\right]\right]\right]
$$

and

$$
\left.E\left[\mid P_{i t}-E\left[P_{i t}\right]\right]\right]=\sum_{k=0}^{n_{i t}} \mid \frac{k}{n_{i t}}-E\left[P_{i t}\right] C_{k}^{n_{i t}}\left(E\left[P_{i t}\right]\right)^{k}\left(1-E\left[P_{i t}\right]\right)^{n i t-k}
$$

where $P_{i t}$ is the percentage derived by dividing the sum of the buy-side recommendations with the total recommendations made by analysts for stock $i$ during month $t$ and $E_{E}\left[P_{i t}\right]$ is the expected proportion. $\left.E\left[\mid P_{i t}-E\left[P_{i t}\right]\right]\right]$ is an adjustment that ensures random variations that approximate the expected proportion of buy recommendations, and is calculated by assuming a binomial distribution of buy recommendations per month. The binomial parameter $n_{i t}$ represents the count of recommendations made on stock $i$ during month $t$. 
For the distinction of buy-herding versus sell-herding, the extension of the LSV model by Brown et al. (2009) is adopted as follows, where $B H M_{i t}$ represents the buy-herding and $S H M_{i t}$ the sell-herding:

$$
\begin{aligned}
& B H M_{i t}=H M_{i t} \mid P_{i t}>E\left[P_{i t}\right] \\
& S H M_{i t}=H M_{i t} \mid P_{i t}<E\left[P_{i t}\right]
\end{aligned}
$$

$P_{i t}>E\left[P_{i t}\right]$ implies that the majority of analysts recommend buying a stock, which results in a greater proportion of buy-recommendations, or buy-herding. By contrast, $P_{i t}<E\left[P_{i t}\right]$ implies a lower proportion of buy-recommendations, thus becoming sell-herding.

\subsection{Raw and Abnormal Future Returns}

For measuring returns, we follow the tradition that the raw and abnormal returns are both estimated according to 3- and 6-month windows as follows. First, the raw stock returns at 3- and 6-month lags after recommendation month $t$ are estimated using Eqs. 5 and 6, respectively.

$$
\begin{aligned}
\text { RAWRTN_} & Q(t)=\left(S_{i, t+3}-S_{i, t}\right) / S_{i . t} \\
\text { RAWRTN_H } & H(t)=\left(S_{i, t+6}-S_{i, t}\right) / S_{i . t}
\end{aligned}
$$

where, $S_{i, t}$ represents the closing price of stock $i$ on the final trading day of month $t ; S_{i, t+3}$ and $S_{i, t+6}$ represent the closing prices of stock $i$ on the final trading day after $t+3$ month and $t+6$ month, respectively.

Second, the abnormal stock returns are estimated at the same lags using Eqs. 7 and 8.

$$
\begin{aligned}
& \text { ABRTN_Q } Q(t)=\left(S_{i, t+3} / S_{i, t}\right)-\left(S_{m, t+3} / S_{m, t}\right) \\
& A B R T N_{-} H(t)=\left(S_{i, t+6} / S_{i, t}\right)-\left(S_{m, t+6} / S_{m, t}\right)
\end{aligned}
$$

where, $S_{m, t}$ represents the closing index of the Shanghai Stock Exchange composite index on the final trading day of month $t ; S_{m, t+3} \& S_{m, t+6}$ represent the closing indices of the Shanghai Stock Exchange composite index on the final trading day after $t+3$ month and $t+6$ month, respectively.

\subsection{Explanatory Variables}

In practice, analyst reports often list various reasons and financial forecasts to justify their recommendations. To confirm whether or not recommendations are subject to certain firm characteristics, this study classifies firm characteristics into four categories: firm fundamental characteristics, growth opportunities, market characteristics, and equity structure characteristics. In general, these variables are calculated on quarterly bases prior to month t, except for the stock return (RTNP), stock turnover (TURN), upgrade, downgrade, and dummy variables (IPO and state). These variables are explained as follows.

\subsubsection{Firm Fundamental Characteristics}

There are five financial variables in this set of characteristics that are often considered by analysts, including firm size (Size), debt-to-assets ratio (Debt), past performance (ROA), non-operating item-to-sales rate (Nonop), and inventory turnover (Inventory). Because of the transition of the China stock market, firm size was estimated by a firm's total assets, instead of market capitalization (Note 2), at the end of its most recent quarter. The leverage (Debt) is often regarded as one of the solutions to agency problems between managers and shareholders, and a debt yields a beneficial tax shield for a firm. Nevertheless, high leverage may increase the likelihood of default and create harsh financial constraints. An increase in leverage may pose underinvestment, thus reducing a firm's value and stock price (Myer, 1977; Cai and Zhang, 2011). The ROA is often used as a control variable for performance (Allayannis and Simko, 2009). For the present study, it is used for past performance, as in Yu (2008). Finally, the non-operating item-to-sales rate and inventory turnover represent the sustainable earning and inventory management efficiency.

\subsubsection{Growth Opportunities}

Three indicators are considered predictors of future growth: sales growth rate (SG), market-to-book ratio (PB), and assets growth rate (ASSETG). Lakonishok et al. (1994) showed that firms of high growth in previous sales usually pose lower subsequent stock returns, implying that investors are likely to overvalue high-growth firms. Fama and French (1993) showed that firms with low market-to-book ratio earn higher returns than those with high market-to-book ratio. Examining the asset growth in the United State, Cooper et al. (2008) and Li and 
Sullivan (2011) found that firms with higher asset growth yield poorer subsequent returns than do those with lower growth rates. For example, Cooper et al. (2008) found that firms with low asset growth rates gain subsequent annualized risk adjusted returns by $9.1 \%$, whereas firms with high asset growth rates lose $10.4 \%$, resulting in a wide gap (19.5\% per year). Cooper's findings are similar to those of Gray and Johnson (2011), who examined the Australia stock market and found similar results.

\subsubsection{Market Characteristics}

Stock return (RTNP) and stock turnover (TURN) are adopted to show stock trading activities, which are calculated on monthly basis prior to month $t$. Besides, the 'Upgrade' and 'Downgrade' representing the revision of stock recommendations by analysts are also considered in this set of characteristics.

The impacts of stock return are mixed. The price momentum effect (Jegadeesh and Titman, 1993; Jegadeesh et al., 2004) states that the previous winning stocks have higher chances to gain in the future. However, the contrarian investment strategy (Chou et al., 2007) is also profitable by purchasing past loser stocks and selling the winners. Stock turnover is hired for private information measuring. Lee and Swaminathan (2000) showed that high (low) trading volume stocks exhibit glamor (value) characteristics, and earn lower (higher) subsequent returns. They also note that analysts provide lower (higher) long-term earnings growth forecasts for low (high) volume stocks, but low (high) volume firms experience significantly better (worse) future operating performance. However, Jegadeesh et al. (2004) found that analysts generally prefer "glamor" stocks to "value" stocks. In particular, they showed that the stocks with low turnovers receive favorable recommendations from analysts.

\subsubsection{Equity Structure Characteristics}

The final four variables are based on equity structures: institutional ownership (INST), percentage changes in institutional ownership ( $\triangle \mathrm{INST}$ ), newly listed firms (IPO), and state-owned enterprises (State). It is known that the holdings and changes of institutional investors (either foreign or domestic) in the China stock market are informative indicators of stock price. We suspect that the same information may affect the recommendations made by analysts. In addition, the China stock market is unique for government policy that strongly affects IPOs in China markets; this market is sentimental by government encouraging or retarding new listing. "IPO" is a dummy variable in which " 1 " stands for newly listed within one year prior to month $t$, and " 0 " otherwise.

Most of the China's state-owned enterprises (SOEs) are large firms and some may be monopolistic in their industries. They play a crucial role in government policy because of their accesses to government resources. SOEs are concerned by investors in the light of operating efficiency and uncertainty. For example, Wei and Varela (2003) suggested that state ownership poses a negative effect on firm value (measured by using Tobin's Q). Therefore, this study includes state ownership (State) as an explanatory variable.

\subsection{Bull and Bear Market Conditions}

Christie and Huang (1995) and Chang et al. (2000) have noted that investor-herding behavior might be more pronounced during periods of market stress. Because the direction of market returns may affect most investors' investment decisions, this study examines similar asymmetries that may arise in the herding behavior of analysts because of the market rising either or falling.

As an emerging market, China's stock prices have fluctuated dramatically in recent years. This study uses the Shanghai Stock Exchange composite index to distinguish the bull and bear markets. Accordingly, July 2005October 2007 and November 2008-September 2009 are the periods of the bull market, and the two bear market periods are March 2004-June 2005 and November 2007-October 2008.

\section{Empirical Results}

\subsection{Do Analysts Herd on Recommendations?}

This study first adopts the LSV herding measure to estimate the herding tendency of analysts regarding each stock. Second, the Brown et al. (2009) modification of the LSV is applied to classify the recommendations of analysts into two sub-samples: buy-recommendations and sell-recommendations. The $t$-test and nonparametric median Kruskal-Wallis tests are used to compare the two sub-samples. This study also examines whether analyst herding varies under different market conditions.

Table 2 presents the descriptive statistics for the analyst herding tendency of each sample. According to Table 2, there are 16,546 observations in the buy-recommendation sub-sample, which is significantly greater than that $(12,983)$ in the sell-recommendation sub-sample. The mean value of sell-herding $(0.081)$ is significantly greater than buy-herding $(-0.011)$ at a $1 \%$ statistical level, indicating that analysts herd more often on 
sell-recommendations than on buy-recommendations (Panel A of Table 3). Table 2 also shows that the standard deviation of sell-herding $(0.178)$ is much greater than that of buy-herding $(0.115)$, suggesting that the magnitude of differences is wider in sell-recommendations than in buy-recommendations.

Table 2. Descriptive statistics of analysts' herding

\begin{tabular}{llll}
\hline & All-herding & Buy-herding & Sell-herding \\
\hline Mean & 0.030 & -0.011 & 0.081 \\
Median & 0.004 & -0.022 & 0.062 \\
$\mathrm{SD}$ & 0.153 & 0.115 & 0.178 \\
Maximum & 0.583 & 0.420 & 0.583 \\
Minimum & -0.250 & -0.250 & -0.249 \\
$\mathrm{~N}$ & 29,529 & 16,546 & 12,983 \\
\hline
\end{tabular}

The greater herding magnitude in sell-recommendations may be attributed to two reasons. First, as mentioned in Section 2.1, analysts may encounter pressure from their underwriting associates or become indebted to the liaisons of studied firms. Analysts issuing favorable recommendations may be compensated with more information from the recommended firms to increase their forecast accuracy (Chen and Matsumoto, 2006). Moreover, conflicts of interests frequently occur in China's stock markets. Sell-side analysts are tasked with the mission of earning commissions from buy-side money management firms, such as mutual funds and private equities. Therefore, issuing an unfavorable recommendation regarding money management firms' heavy holding stocks is difficult for analysts. Specifically, issuing negative opinions is likely to offend not only money management firms but also the analysts' underwriting associates and the studied firms. Therefore, when analysts are obligated to downgrade the rating of a firm, they may choose to follow their peers to share the blame. Furthermore, if advice is incorrect, the negligence of following a group of analyst peers is more excusable.

Second, because analysts are generally reluctant to submit negative recommendations, once an unfavorable recommendation is revealed, how would the other analysts respond to this signal? By accounting for the previous findings indicating that short sellers in stock markets are informed traders, analysts might consider that the one who issues the negative opinion has more private information than the others do (Christophe et al., 2004; Boehmer et al., 2008; Christophe et al., 2010). Thus, analysts are better off following the downgrade to save their clients from loss. This might explain why the herding magnitude is substantially higher in sell-herding than in buy-herding.

$T$-tests on the mean difference and nonparametric Kruskal-Wallis tests on the median difference are performed to examine the above effects. The results are shown in Panels C and D in Table 3. Sell-herding is significantly greater than buy-herding in both the bull and bear markets. Cross examinations on the sub-samples reveal that the greatest herding appeared as sell-herding in the bear market. A possible explanation is that, when bad news spreads widely in the bear market, there are enough unfavorable macroeconomic excuses to make analysts feel safe in releasing their downgrades. The bear market provides favorable factors for escalating the downgrading and, hence, induces intensive herding among analysts. ANOVA analyses on the interaction effects between the analysts' (buy/sell) herding and the (bull/bear) market conditions were performed, and the results statistically support the above findings at a significant level $(\mathrm{F}=51.50 ; \mathrm{p}<0.01)$.

Table 3. T-tests and Kruskal-Wallis tests of herding in various sub-samples

\begin{tabular}{llllll}
\hline & \multicolumn{3}{c}{ K-W test } \\
\hline Period & $\mathrm{N}$ & Mean & $t$ value & Median & $\chi^{2}$ \\
\hline Panel A: & & & & & \\
Buy-herding & 16,546 & -0.011 & $-53.402^{* * *}$ & -0.021 & $1886.131^{* * *}$ \\
Sell-herding & 12,983 & 0.081 & $(0.000)$ & 0.062 & $(0.000)$ \\
\hline Panel B : & & & & & \\
Bull market & 18,621 & 0.031 & -0.203 & 0.011 & $11.917^{* * *}$ \\
Bear market & 9,511 & 0.032 & $(0.839)$ & 0.002 & $(0.001)$ \\
\hline Panel C: & & & & & \\
Buy-herding / Bull market & 10,502 & -0.007 & $5.530^{* * *}$ & -0.038 & $94.250^{* * *}$ \\
Buy-herding / Bear market & 5,432 & -0.017 & $(0.000)$ & -0.021 & $(0.000)$ \\
\hline Panel D: & & & & & \\
Sell-herding / Bull market & 8,119 & 0.081 & $-4.688^{* * *}$ & 0.082 & $20.450^{* * *}$ \\
Sell-herding / Bear market & 4,079 & 0.097 & $(0.000)$ & 0.052 & $(0.000)$ \\
\hline
\end{tabular}




\subsection{Does Herding Affect Returns?}

The 3- and 6-month returns after the recommendations in various market conditions are analyzed on herding in four quartiles to answer the question of whether herding is associated with returns. The results are shown in Table 4. In general, analysts' herding is correlated with stock returns at a 1\% significant level (Panel A in Table 4). In summary, the herding of stock recommendations made by analysts affects returns.

Additional analyses on returns (abnormal and raw returns) with respect to market sentiments (bull and bear markets) and herding (buy- versus sell-herding) reveal compelling findings. During the bull market, the highest returns of buy-herding were found at the least herding quartile (Q1). Take a closer look at the heavily herding quartile (Q4), we find that stocks with buy-herding achieve positive returns. Surprisingly, investors buying the stocks with sell-herding yield even higher returns than those with buy-herding (see Q4, Panel B in Table 4). Therefore, investors may earn higher return by longing the stocks with lowest level of analyst buy-herding or those with highest level of analyst sell-herding.

Contrary to the bull market, returns of sell-herding are well below those of buy-herding during the bear market (see Q4, Panel C in Table 4). Again, at the highest herding level (Q4), the 3-month (6-month) loss is -18.43\% $(-22.91 \%)$, which is substantially below the average of $-11.44 \%(-14.12 \%)$. This implies that analysts' "sell" recommendations in the bear market are valuable, and following their advice could prevent substantial losses. Regarding buying recommended stocks in the bear market, only the stocks in quartile Q2 recommended by few analysts exhibit the highest performance, and the 3-month short-term returns are positive. The stocks recommended for purchase by analysts had positive abnormal returns in the bear market (i.e., the average returns exceed the index); however, the raw returns are negative, indicating that investment suggestions made by analysts may result in losses.

Table 4. The relations between subsequent returns and levels of analysts herding

\begin{tabular}{|c|c|c|c|c|c|c|c|}
\hline \multirow[b]{2}{*}{ Returns (\%) } & \multicolumn{5}{|c|}{ Herding Measure } & \multirow[b]{2}{*}{ F-test } & \multirow[b]{2}{*}{ (p-value) } \\
\hline & Average & Q1 (smallest) & Q2 & Q3 & Q4 (highest) & & \\
\hline \multicolumn{8}{|l|}{ Panel A: All } \\
\hline ABRTN_Q & 4.912 & 6.046 & 3.903 & 4.691 & 5.003 & 8.84 & $(0.000)^{* * *}$ \\
\hline ABRTN_H & 8.833 & 11.054 & 6.648 & 7.024 & 10.593 & 22.81 & $(0.000)^{* * *}$ \\
\hline RAWRTN_Q & 10.344 & 11.349 & 8.820 & 10.315 & 10.890 & 7.62 & $(0.000)^{* * *}$ \\
\hline RAWRTN_H & 21.610 & 22.756 & 19.033 & 19.996 & 24.658 & 13.74 & $(0.000)^{* * *}$ \\
\hline \multicolumn{8}{|c|}{ Panel B: Bull market } \\
\hline \multicolumn{8}{|l|}{ Buy-herding } \\
\hline ABRTN_Q & 5.299 & 7.475 & 2.789 & 6.289 & 4.741 & 13.70 & $(0.000)^{* * *}$ \\
\hline ABRTN_H & 9.566 & 11.083 & 10.033 & 8.781 & 8.376 & 1.87 & $(0.133)$ \\
\hline RAWRTN_Q & 22.469 & 24.340 & 22.421 & 21.404 & 21.763 & 4.45 & $(0.004)^{* *}$ \\
\hline RAWRTN_H & 40.854 & 39.608 & 47.302 & 35.569 & 40.696 & 20.47 & $(0.000)^{* * *}$ \\
\hline \multicolumn{8}{|l|}{ Sell-herding } \\
\hline ABRTN_Q & 5.634 & 6.266 & 5.372 & 1.946 & 8.990 & 21.85 & $(0.000)^{* * *}$ \\
\hline ABRTN_H & 10.751 & 9.689 & 7.251 & 11.991 & 14.030 & 7.41 & $(0.000)^{* * *}$ \\
\hline RAWRTN_Q & 22.460 & 23.826 & 19.444 & 20.519 & 26.061 & 18.53 & $(0.000)^{* * *}$ \\
\hline RAWRTN_H & 42.826 & 42.220 & 37.047 & 46.819 & 45.064 & 10.77 & $(0.000)^{* * *}$ \\
\hline \multicolumn{8}{|c|}{ Panel C: Bear market } \\
\hline \multicolumn{8}{|l|}{ Buy-herding } \\
\hline ABRTN_Q & 5.204 & 2.968 & 8.253 & 3.915 & 5.527 & 15.36 & $(0.000)^{* * *}$ \\
\hline ABRTN_H & 8.735 & 4.312 & 14.721 & 7.800 & 7.712 & 25.27 & $(0.000)^{* * *}$ \\
\hline RAWRTN_Q & -12.096 & -17.976 & -6.052 & -13.328 & -11.442 & 39.28 & $(0.000)^{* * *}$ \\
\hline RAWRTN_H & -13.939 & -28.684 & 1.590 & -15.752 & -14.123 & 90.21 & $(0.000)^{* * *}$ \\
\hline \multicolumn{8}{|l|}{ Sell-herding } \\
\hline ABRTN_Q & 3.224 & 4.863 & 0.446 & 4.843 & 2.628 & 10.93 & $(0.000)^{* * *}$ \\
\hline ABRTN_H & 6.428 & 8.438 & -0.387 & 10.690 & 6.620 & 22.36 & $(0.000)^{* * *}$ \\
\hline RAWRTN_Q & -12.442 & -12.854 & -9.535 & -8.875 & -18.430 & 27.36 & $(0.000)^{* * *}$ \\
\hline RAWRTN_H & -13.847 & -14.315 & -15.444 & -2.987 & -22.911 & 31.49 & $(0.000)^{* * *}$ \\
\hline
\end{tabular}

Consequently, the stocks heavily recommended for purchase by analysts (Q4) do not have the highest returns in the bull and bear markets, indicating that when more people recommend or focus on one stock, they tend to 
explore the reasons for buy-recommendations more comprehensively. When the public knows about benefits, stock prices lose momentum to rise. However, this result may also be caused by conflicts of interest that frequently occur in China's stock market. Most research departments of Chinese brokerage firms receive revenues primarily from fund commissions. Therefore, brokerage firms urge analysts to pursue optimal analyst rankings (e.g., the best analyst ranking of New Fortune Magazine), which are based on a vote by research report readers (i.e., institutional investors), to enhance the brand images of companies. Furthermore, brokerage firms expect to earn more commissions through services offered by analysts to fund managers. To achieve these goals, analysts must ingratiate fund managers or other institutional investors. Therefore, analysts publish buy-recommendations for stocks held by mutual funds to stimulate stock prices and increase the net asset value of funds. The buy-recommendations from these non-independent analysts frequently result in poor follow-up stock returns.

Apparently, the market reaction to buy-herding and sell-herding is significantly asymmetric. These results echoes Welch' s (2000) finding that new added-to sell recommendations are more predictive than new added-to buy recommendations, and market responses to new sell recommendations are of greater magnitude in the post-recommendation period.

\subsection{Firm Characteristics for Herding}

As mentioned, analysts file their recommendations according to certain firm and industry level information to justify their conclusions. In the present study, four sets of characteristics are account for: firm fundamental variables, growth opportunity, market conditions, and equity structure characteristics. The descriptive statistics with respect to these explanatory variables are shown in Table 5. In addition to the entire sample analysis (All-herding column in Table 5), the entire sample is further divided into two sub-samples: sell-herding (Buy-herding column) and buy-herding (Sell-herding column).

The corresponding panel data regression results are listed in Table 6. Because of the offset effect of the two opposite behaviors of buy-herding and sell-herding, a few variables in all-herding regression are not significant but become significant in sub-sample regressions. Therefore, the discussions on explanatory variables in the following sections focus mainly on the sub-sample results.

First, the regressions of a firm's fundamental characteristics (Table 6) show that analysts favor stocks with large caps, lower debt ratios, and higher past performance (higher ROA), but avoid recommending the purchase of stocks with higher non-operating item-to-sales ratio. Lin et al., (2011) reported that herding according to analyst recommendations increases with firm size, and positively correlates with future returns. In addition, an obvious reason for analysts' interests in large sized stocks is because these firms disclose their information more often and are more transparent; therefore, information asymmetry rarely occurs (Kim and Zapatero, 2009). The results of the squares of size show an inverse U-shaped relationship between herding and firm size. Regarding the leverage, firms with higher debt ratios experience a higher likelihood of default, and are underinvested in the future (Myer, 1977; Cai and Zhang, 2011). Thus, firms with lower debt ratios are more likely to receive favorable recommendations.

Analysts who herd to recommend buying the stocks with higher performance in the past (higher ROA) and selling those with poor performance (lower ROA) are indicative of analysts inferring that the outperformers in the past will continue to perform higher in the future. Furthermore, analysts assign a higher rating to a firm with higher earnings from its core business operations. This result corresponds with the finding of Bradshaw and Sloan (2002), who found that "street earning" (Note 3) reflects a firm's earnings per share reported on a "continued operations" basis. Hanna (2001) explored the effect of special items on analysts' earnings forecasts and indicated an increasing error in analysts' forecasts when special items exist. Non-operating income seems to be easily manipulated by management, whereas operating income items are persistent and have higher predictive power. Analysts thus prefer a lower ratio of non-operating item-to-sales, and herd to recommend selling higher ratios.

Second, variables regarding the growth opportunity are significantly related to herding in both of the sub-samples, except for the sales growth rate. The stock price of a firm with a lower market-to-book ratio may imply that the stock is undervalued; therefore, it might attract the attention of analysts (Rau and Vcrmaelen, 1998; André et al., 2004; Jegadeesh et al., 2004). This is confirmed by the results listed in Table 6, in which the sell-herding is positively affected by the greater market-to-book ratio (with coefficient $=1.818, \mathrm{p}<0.01$ ). Concurrently, the buy-herding is negatively affected (coefficient $=-0.954, \mathrm{p}<0.01$ ). Analysts also herd to recommend buying firms with higher asset growth rates (coefficient $=0.001, p<0.1$ ) and selling firms with lower growth rates (coefficient $=-0.142, \mathrm{p}<0.001$ ). This may imply that analysts generally agree that a firm 
with substantial asset growth has superior operating prospects. Nevertheless, this phenomenon is inconsistent with the findings of Cooper et al. (2008) and Gray and Johnson (2011). A possible explanation for this anomaly may be due in market maturity. In developed countries, a firm's asset expansion is generally achieved by mergers and acquisitions, public equity offerings, public debt offerings, and bank loan initiations (Cooper et al., 2008). However, emerging markets such as China have been subjected to planned economic systems for a long period, in which firms may expand aggressively by adopting a specific policy to endow assets directly, to execute mergers and acquisitions under a low premium, or to restructure the assets of distressed companies. Under a favorable policy supported by the government, investors as well as analysts expect that firms with a higher rate of assets growth will have more growth opportunities and achieve higher performance.

Table 5. Descriptive statistics for explanatory variables

\begin{tabular}{|c|c|c|c|c|c|c|c|c|c|}
\hline \multirow{2}{*}{$\begin{array}{l}\text { Dependent } \\
\text { Variable }\end{array}$} & \multicolumn{3}{|c|}{ All-herding } & \multicolumn{3}{|c|}{ Buy-herding } & \multicolumn{2}{|c|}{ Sell-herding } & \multirow[b]{2}{*}{ SD } \\
\hline & Mean & Median & $\mathrm{SD}$ & Mean & Median & SD & Mean & Median & \\
\hline \multicolumn{10}{|c|}{ Firm Fundamental Characteristics } \\
\hline Size & 15.22 & 15.16 & 1.19 & 15.13 & 15.04 & 1.15 & 15.34 & 15.27 & 1.22 \\
\hline Debt $(\%)$ & 48.81 & 49.50 & 20.44 & 48.64 & 49.64 & 18.33 & 49.02 & 49.32 & 22.85 \\
\hline ROA (\%) & 1.62 & 1.42 & 2.83 & 2.02 & 1.72 & 2.42 & 1.11 & 1.06 & 3.20 \\
\hline Nonopt (\%) & 0.01 & -0.01 & 26.93 & -0.33 & -0.01 & 22.46 & 0.46 & -0.01 & 31.72 \\
\hline Inventory & 15.67 & 1.18 & 435.52 & 18.03 & 1.14 & 547.21 & 12.64 & 1.23 & 220.29 \\
\hline \multicolumn{10}{|c|}{ Growth Opportunity } \\
\hline SG (\%) & 53.06 & 18.02 & 715.64 & 67.68 & 21.47 & 876.55 & 34.17 & 13.14 & 424.82 \\
\hline PB & 3.95 & 2.82 & 4.58 & 4.38 & 3.24 & 5.35 & 3.40 & 2.42 & 3.28 \\
\hline $\operatorname{ASSETG}(\%)$ & 43.67 & 16.21 & 1570.4 & 60.90 & 19.24 & 2096.73 & 21.70 & 12.23 & 52.55 \\
\hline \multicolumn{10}{|c|}{ Market Characteristics } \\
\hline RTNP (\%) & 3.13 & 2.21 & 18.32 & 3.59 & 2.77 & 18.51 & 2.54 & 1.49 & 18.06 \\
\hline TURN (\%) & 51.24 & 38.10 & 44.77 & 50.27 & 38.01 & 42.74 & 52.48 & 38.23 & 47.20 \\
\hline Upgrade & 0.06 & 0 & 0.26 & 0.07 & 0 & 0.29 & 0.05 & 0 & 0.22 \\
\hline Downgrade & 0.07 & 0 & 0.28 & 0.05 & 0 & 0.23 & 0.09 & 0 & 0.33 \\
\hline Bull & 0.63 & 1 & 0.48 & 0.63 & 1 & 0.48 & 0.63 & 1 & 0.48 \\
\hline Bear & 0.32 & 0 & 0.47 & 0.33 & 0 & 0.47 & 0.31 & 0 & 0.46 \\
\hline \multicolumn{10}{|c|}{ Equity Structure Characteristics } \\
\hline INST (\%) & 24.30 & 20.68 & 21.18 & 28.25 & 27.05 & 21.51 & 19.26 & 13.79 & 19.64 \\
\hline$\triangle \mathrm{INST1}$ & 0.26 & 0 & 0.44 & 0.30 & 0 & 0.45 & 0.20 & 0 & 0.40 \\
\hline$\triangle \mathrm{INST2}$ & 0.24 & 0 & 0.43 & 0.20 & 0 & 0.40 & 0.29 & 0 & 0.46 \\
\hline$\triangle \mathrm{INST3}$ & 0.25 & 0 & 0.43 & 0.21 & 0 & 0.41 & 0.30 & 0 & 0.45 \\
\hline IPO & 0.05 & 0 & 0.22 & 0.06 & 0 & 0.23 & 0.05 & 0 & 0.21 \\
\hline State & 0.19 & 0 & 0.39 & 0.17 & 0 & 0.38 & 0.21 & 0 & 0.41 \\
\hline
\end{tabular}

Description: This table provides descriptive statistics. Size is the natural logarithm of total asset for firm $i$ in the quarter prior to month $t$. Debt is the debt-to-assets ratio for firm $i$ in the quarter prior to month $t$. ROA is the return on assets for firm $i$ in the quarter prior to month $t$. Nonop is the non-operating profit-to-sales rate for firm $i$ in the quarter prior to month $t$. Inventory is the inventory turnover for firm $i$ in the quarter prior to month $t$. SG is the sales growth rate for firm $i$ in the quarter prior to month $t$. PB is the market-to-book ratio for firm $i$ in the quarter prior to month $t$. ASSETG is the asset growth rate for firm $i$ in the quarter prior to month $t$. RTNP is the stock price return for firm $i$ in the month prior to month $t$. TURN is the stock turnover for firm $i$ in the month prior to month $t$. Upgrade (or Downgrade) is the number of analysts' upgrade (or downgrade) for firm $i$ in month $t$. INST is the fraction share held by institutional investors for firm $i$ in the quarter prior to month $t . \triangle \mathrm{INST}$ is the percentage change of institutional investors holdings for firm $i$ in the quarter prior to month $t$. IPO is the dummy variable that equals one if firm $i$ is newly listed one year prior to month $t$, and zero otherwise. State is the dummy variable that equals one if the ownership is controlled by central government, and zero otherwise.

Third, regarding market characteristics, analysts do not seem to favor stocks with low returns in the previous month. This may imply that analysts believe that present stock prices are correlated with previous prices in the sell-herding sub-sample, coinciding with the positive momentum effect (Jegadeesh et al., 2004). This phenomenon, however, is not significant in buy-herding. For the trading volume, analysts may herd to make sell-recommendations on firms with higher turnover in the previous month. This result supports the empirical results of Lee and Swaminathan (2000), in which stocks with high (low) past turnover ratios exhibit glamor (value) characteristics and earn lower (higher) subsequent returns. Therefore, the magnitude of turnover in the previous month negatively correlates with buy-herding, but positively correlates with sell-herding. Another piece of evidence of analysts' following each other to make investment advice is that when analysts upgrade (downgrade) their rating on a firm, the magnitude of buy-herding (sell-herding) on the firm accordingly enlarges. 
Finally, regarding equity structures, analysts prefer firms owned mostly by institutional investors, which is consistent with the findings of Frankel et al. (2006). However, regarding the institutional ownership change of a firm, analysts agree with the suggestions of Dasgupta et al. (2011), who stated that stocks persistently bought by institutional investors over the final four quarters underperform those persistently sold by them. Therefore, if institutional investors increase (decrease) their holdings in one stock in the last quarter, analysts would herd to issue sell (buy) recommendations.

Past research (Bradley et al., 2008) documented a negative and significant relationship between IPO long-term performance and initial return. China's IPOs, because of the fast-growing market and the government's encouragement, grew fast during our sample period, thus attracting investors and security analysts worldwide. However, in China's stock market, companies frequently employ financial statement fraud to list their securities on a public exchange (IPO), and most of these companies exhibit significant declines in performance after they are listed. For example, 70 companies going public with help from Ping An Securities during the period from 2009 to 2012, nearly half of these companies were involved in financial fraud or exhibited significant performance declines after being listed (Note 4). Investors lose their confidence in newly listed firms because of fraud in financial reports and because numerous IPOs boast of their future earnings. This may explain our finding that, in China's stock market, analysis exhibit sell-herding tendencies on IPO firms.

Although analysts tend to herd stocks preferred by institutional investors, they do not appear to appreciate state-owned firms. Consequently, the "State" variable is insignificant.

Table 6. Regressions of herding on explanatory variables

\begin{tabular}{|c|c|c|c|c|c|c|}
\hline \multirow{2}{*}{$\begin{array}{l}\text { Dependent } \\
\text { Variable }\end{array}$} & \multicolumn{2}{|c|}{ All-herding } & \multicolumn{2}{|c|}{ Buy-herding } & \multicolumn{2}{|c|}{ Sell-herding } \\
\hline & Coef. & P-value & Coef. & P-value & Coef. & P-value \\
\hline \multicolumn{7}{|c|}{ Firm Fundamental Characteristics } \\
\hline Size & 62.092 & $0.031^{* *}$ & 184.299 & $0.000^{* * *}$ & -242.135 & $0.000^{* * *}$ \\
\hline Size_SQ & -1.443 & 0.117 & -5.427 & $0.000^{* * *}$ & 8.001 & $0.000^{* * *}$ \\
\hline Debt & -0.628 & $0.000^{* * *}$ & -0.512 & $0.000^{* * *}$ & -0.208 & 0.242 \\
\hline ROA & -3.019 & $0.000^{* * *}$ & 3.415 & $0.000^{* * *}$ & -2.737 & $0.000^{* * *}$ \\
\hline Nonopt & 0.112 & $0.003^{* * *}$ & -0.115 & $0.020^{* *}$ & 0.086 & $0.083^{*}$ \\
\hline Inventory & 0.007 & $0.001^{* * *}$ & 0.005 & $0.004^{* * *}$ & 0.013 & $0.039^{* *}$ \\
\hline \multicolumn{7}{|c|}{ Growth Opportunity } \\
\hline SG & -0.003 & $0.030^{* *}$ & -0.002 & 0.129 & -0.004 & 0.197 \\
\hline PB & 0.146 & 0.654 & -0.954 & $0.001^{* * *}$ & 1.818 & $0.006^{* * *}$ \\
\hline ASSETG & 0.001 & 0.341 & 0.001 & $0.053^{*}$ & -0.142 & $0.000^{* * *}$ \\
\hline \multicolumn{7}{|c|}{ Market Characteristics } \\
\hline RTNP & -0.168 & $0.001^{* * *}$ & 0.009 & 0.862 & -0.379 & $0.000^{* * *}$ \\
\hline TURN & 0.170 & $0.003^{* * *}$ & -0.314 & $0.000^{* * *}$ & 0.606 & $0.000^{* * *}$ \\
\hline TURN_SQ & -0.000 & 0.186 & 0.001 & $0.004^{* * *}$ & -0.001 & $0.000^{* * *}$ \\
\hline Upgrade & -5.697 & $0.072^{*}$ & 19.621 & $0.000^{* * *}$ & -49.024 & $0.000^{* * *}$ \\
\hline Downgrade & -5.151 & $0.078^{*}$ & -35.954 & $0.000^{* * *}$ & 7.252 & $0.084^{*}$ \\
\hline Bull & 38.229 & $0.000^{* * *}$ & 11.540 & $0.066^{*}$ & 35.017 & $0.000^{* * *}$ \\
\hline Bear & 37.941 & $0.000^{* * *}$ & -1.985 & 0.750 & 49.505 & $0.000^{* * *}$ \\
\hline \multicolumn{7}{|c|}{ Equity Structure Characteristics } \\
\hline INST & -0.098 & 0.184 & 0.789 & $0.000^{* * *}$ & -0.627 & $0.000^{* * *}$ \\
\hline$\triangle \mathrm{INST} 1$ & -6.456 & $0.014^{* *}$ & -23.398 & $0.000^{* * *}$ & 11.066 & $0.022^{* *}$ \\
\hline$\Delta \mathrm{INST} 2$ & 3.563 & 0.184 & -17.180 & $0.000^{* * *}$ & 17.391 & $0.000^{* * *}$ \\
\hline$\triangle \mathrm{INST3}$ & 10.685 & $0.000^{* * *}$ & -18.370 & $0.000^{* * *}$ & 32.832 & $0.000^{* * *}$ \\
\hline IPO & 3.959 & 0.555 & -5.334 & 0.418 & 26.785 & $0.021^{* *}$ \\
\hline State & 6.636 & 0.434 & 3.239 & 0.557 & -1.899 & 0.870 \\
\hline Intercept & -604.45 & $0.007^{* * *}$ & -1543.15 & $0.000^{* * *}$ & 1834.93 & $0.000^{* * *}$ \\
\hline$\chi^{2}$ & 309.21 & $0.000^{* * *}$ & 755.39 & $0.000^{* * *}$ & 385.73 & $0.000^{* * *}$ \\
\hline$R^{2}$ & 0.0220 & & 0.0739 & & 0.0716 & \\
\hline $\mathrm{N}$ & 25,865 & & 14,644 & & 11,221 & \\
\hline
\end{tabular}

Description: This table lists the relationships between monthly herding measure (HM, BHM and SHM) and various explanatory variables. The variables are listed in detail in Table 2. Estimated parameters, the t-statistics, and R-square values are reported. The sample period is from April 2002 to September 2009. ${ }^{* * * * *}$, and ${ }^{*}$ indicate significance at the $1 \%, 5 \%$, and $10 \%$ (2-tail) levels, respectively. 


\subsection{Bull and Bear Markets}

Further checking of the above findings in the light of the bull versus bear markets are listed in Table 7 . The modeling power is marginally improved according to the $\mathrm{R}^{2}$ indicators, except for the sell-herding sub-sample during the bull market. The findings listed in Table 7 are generally similar to those listed in Table 6 . The exceptions are discussed as follows.

First, the debt-to-assets ratio is insignificant for sell-herding. However, for the bull versus bear markets, opposite impacts appear, but are significant only in the bear market. In other words, the sell-herding of analysts in the bear market is greater with a lower debt-to-assets ratio. Under governmental support, China's state-owned enterprises face little risk of bankruptcy, resulting in loose debt management. Firms with higher state ownership tend to have higher leverage ratios (Su, 2004; Li et al., 2009). Therefore, the bankruptcy likelihood of state-owned firms with higher debt ratios is not necessarily higher than that of private firms with lower debt ratios. The results correspond with those of George and Hwang (2010). Moreover, the coefficient of the non-operating income is simply significant in the bear market.

Table 7. Regressions of herding measures on explanatory variables in bull and bear markets

\begin{tabular}{|c|c|c|c|c|c|c|c|c|}
\hline \multirow{2}{*}{$\begin{array}{l}\text { Dependent } \\
\text { Variable }\end{array}$} & \multicolumn{4}{|l|}{ Bull } & \multicolumn{4}{|l|}{ Bear } \\
\hline & \multicolumn{2}{|c|}{ Buy-herding } & \multicolumn{2}{|c|}{ Sell-herding } & \multicolumn{2}{|l|}{ Buy-herding } & \multicolumn{2}{|c|}{ Sell-herding } \\
\hline \multicolumn{9}{|c|}{ Firm Fundamental Characteristics } \\
\hline & Coef. & P-value & Coef. & P-value & Coef. & $\mathrm{P}$-value & Coef. & P-value \\
\hline Size & 121.025 & $0.000^{* * *}$ & -197.499 & $0.000^{* * *}$ & 238.705 & $0.000^{* * *}$ & -267.126 & $0.000^{* * *}$ \\
\hline Size_SQ & -3.479 & $0.000^{* * *}$ & 6.409 & $0.000^{* * *}$ & -7.302 & $0.000^{* * *}$ & 8.844 & $0.000^{* * *}$ \\
\hline Debt & -0.324 & $0.007^{* * *}$ & 0.339 & 0.121 & -0.585 & $0.000^{* * *}$ & -0.858 & $0.004^{* * *}$ \\
\hline ROA & 3.535 & $0.000^{* * *}$ & -3.844 & $0.000^{* * *}$ & 2.754 & $0.001^{* * *}$ & -2.826 & $0.001^{* * *}$ \\
\hline Nonopt & -0.249 & 0.218 & -0.010 & 0.957 & -0.086 & $0.081^{*}$ & 0.125 & $0.012^{* *}$ \\
\hline Inventory & 0.002 & 0.463 & 0.030 & 0.139 & 0.008 & $0.000^{* * *}$ & 0.008 & 0.209 \\
\hline \multicolumn{9}{|c|}{ Growth Opportunity } \\
\hline SG & -0.001 & 0.539 & -0.002 & 0.611 & -0.002 & 0.343 & -0.007 & 0.264 \\
\hline PB & -1.732 & $0.000^{* * *}$ & 2.593 & $0.006^{* * *}$ & -0.665 & $0.056^{*}$ & 3.267 & $0.000^{* * *}$ \\
\hline ASSETG & 0.001 & $0.057^{*}$ & -0.142 & $0.000^{* * *}$ & 0.072 & $0.011^{* *}$ & -0.171 & $0.008^{* * *}$ \\
\hline \multicolumn{9}{|c|}{ Market Characteristics } \\
\hline RTNP & 0.051 & 0.402 & -0.444 & $0.000^{* * *}$ & -0.097 & 0.196 & -0.222 & 0.158 \\
\hline TURN & -0.283 & $0.000^{* * *}$ & 0.521 & $0.000^{* * *}$ & -0.616 & $0.000^{* * *}$ & 0.972 & $0.000^{* * *}$ \\
\hline TURN_SQ & 0.001 & $0.064^{*}$ & -0.001 & $0.022^{* *}$ & 0.002 & $0.002^{* * *}$ & -0.004 & $0.001^{* * *}$ \\
\hline Upgrade & 19.922 & $0.000^{* * *}$ & -53.712 & $0.000^{* * *}$ & 31.527 & $0.000^{* * *}$ & -62.592 & $0.000^{* * *}$ \\
\hline Downgrade & -36.444 & $0.000^{* * *}$ & 5.658 & 0.272 & -35.507 & $0.000^{* * *}$ & 16.417 & $0.012^{* *}$ \\
\hline \multicolumn{9}{|c|}{ Equity Structure Characteristics } \\
\hline INST & 0.910 & $0.000^{* * *}$ & 0.079 & 0.614 & 0.727 & $0.000^{* * *}$ & -2.031 & $0.000^{* * *}$ \\
\hline$\Delta \mathrm{INST1}$ & -30.199 & $0.000^{* * *}$ & 2.347 & 0.683 & -17.482 & $0.000^{* * *}$ & 33.556 & $0.000^{* * *}$ \\
\hline$\Delta \mathrm{INST2}$ & -22.803 & $0.000^{* * *}$ & 26.688 & $0.000^{* * *}$ & -16.991 & $0.000^{* * *}$ & 8.875 & 0.259 \\
\hline$\triangle \mathrm{INST3}$ & -25.494 & $0.000^{* * *}$ & 39.122 & $0.000^{* * *}$ & -16.936 & $0.000^{* * *}$ & 23.186 & $0.004^{* * *}$ \\
\hline IPO & 5.474 & 0.540 & 25.105 & 0.102 & -7.317 & 0.504 & -16.086 & 0.415 \\
\hline State & 2.193 & 0.736 & 2.562 & 0.840 & 7.687 & 0.328 & -0.632 & 0.971 \\
\hline Intercept & -1100.85 & $0.000^{* * *}$ & 1513.27 & $0.000^{* * *}$ & -1930.37 & $0.000^{* * *}$ & 1971.28 & $0.001^{* * *}$ \\
\hline$\gamma^{2}$ & 526.61 & $0.000^{* * *}$ & 252.97 & $0.000^{* * *}$ & 332.08 & $0.000^{* * *}$ & 187.91 & $0.000^{* * *}$ \\
\hline$R^{2}$ & 0.0744 & & 0.0599 & & 0.0900 & & 0.0762 & \\
\hline $\mathrm{N}$ & 9,531 & & 7,267 & & 4,749 & & 3,537 & \\
\hline
\end{tabular}

Description: This table lists the relationships between monthly herding measures (BHMs and SHMs) and various explanatory variables in both bull and bear markets. The variables are listed in detail in Table 2. Estimated parameters, the t-statistics, and R-square values are reported. The sample period is from April 2002 to September 2009. ${ }^{* * *},{ }^{* *}$, and ${ }^{*}$ indicate significance at the $1 \%, 5 \%$, and $10 \%$ (2-tail) levels, respectively.

Second, the finding that the future trend of stock prices continues to follow past trends in the sell-herding sub-sample appears only in the bull market. In other words, analysts are more likely to issue sell-recommendations to firms with lower rates of return in the bull market. This finding supports the argument of Cooper et al. (2004) and Huang (2006) that market state is critical to the profitability of momentum strategy. 
Finally, regarding equity structure, analysts make buy recommendations for stocks with more institutional ownership in both up and down markets, but significantly make sell recommendations for less institutional ownership simply when the market exhibits a downward trend. Furthermore, in the sell-herding sub-sample, the levels of sell-herding vary according to changes in institutional ownership. The IPO variable becomes insignificant after distinguishing the bull and bear markets.

\section{Conclusion}

This is the first study to apply the LSV method to examine the analysts' herding behavior on recommendations, and investigates whether analysts in China's stock market are subject to the herding effect. After distinguishing buy-recommendation herding and sell-recommendation herding, evidence in this study indicates that analysts extremely herd to make sell-recommendations when the market exhibits a downward trend. After examining the relationships between herd levels and returns, we find that analysts' herding is nonlinearly associated with subsequent stock returns, and these relationships vary according to market sentiments. During the bull market, longing the stocks that analysts herd for sell recommendations gain more returns than do those that analysts herd for buy recommendations. Conversely, during the bear market, shorting the stocks that analysts herd for sell recommendations gain more returns than do those that analysts herd for buy recommendations.

After examining the correlations between herding tendency and firm characteristics, our results show that analysts favor stocks with large caps, higher performance, less non-operating income, lower market-to-book ratios, higher asset growth rates, less trading volume, and higher institutional holdings. Furthermore, analyst upgrades and downgrades cause peers to follow in the bear market. After dividing the buy and sell recommendation sub-samples into the bull and bear markets, we observe some noteworthy changes. The debt-to-assets ratio is significantly related to the sell-herding tendency simply during the bear market periods. In stock price momentum, however, analysts do not significantly herd to make sell recommendations to firms with lower returns in a down market. For equity structure, analysts favor institutional ownership, except for sell-herding in the bull market. Regarding the changes in institutional ownership, the levels of sell-herding vary according to changes in institutional ownership.

This study contributes to the literature in threefold. First, by adopting the LSV measure, we are able to divide the sample into the buy-herding and sell-herding sub-samples. By performing the division, we show that the magnitudes of buy- and sell-herding differ with respect to market sentiments. Second, the consequences of herding on returns are examined. The results show that, in the cases of market sentiments, high herding recommendations may translate to valuable investment advice for investors. Finally, this study examines the specific features of firms that attract analysts to offer buying and selling advice to help market participants evaluate more effectively the herding behavior related to analyst recommendations and improve investment decision making.

\section{Acknowledgements}

As being the affiliated researcher of the Institute for Knowledge Service and Innovation (IKSI) at Yuan Ze University in Taiwan, the third author gratefully acknowledges the access to I/B/E/S data.

\section{References}

Allayannis, G., \& Simko, P. J. (2009). Earnings smoothing, analyst following, and firm value. Working paper. Retrieved from http://ssrn.com/abstract=1361228

André, P., Kooli, M., \& L'Her, J. F. (2004). The long-run performance of mergers and acquisitions: Evidence from the Canadian stock market. Financial Management, 33(4), 27-43.

Baker, H. K., \& Nofsinger, J. R. (2002). Psychological biases of investors. Financial Services Review, 11(2), 97-116.

Banerjee, A. V. (1992). A simple model of herd behavior. Quarterly Journal of Economics, 107, 797-818. http://dx.doi.org/10.2307/2118364

Barber, B., Lehavy, R., McNichols, M., \& Trueman, B. (2001). Can investors profit from the prophets? Security analyst recommendations and stock returns. Journal of Finance, 56(2), 531-563. http://dx.doi.org/10.1111/0022-1082.00336

Bernhardt, D., Campello, M., \& Kutsoati, E. (2006). Who herds? Journal of Financial Economics, 80(3), 657-675. http://dx.doi.org/10.1016/j.jfineco.2005.07.006

Bikhchandani, S., Hirschleifer, D., \& Welch, I. (1992). A theory of fads, fashion, custom and cultural change as informational cascades. Journal of Political Economy, 100(5), 992-1026. http://dx.doi.org/10.1086/261849 
Boehmer, E., Jones, C., \& Zhang, X. (2008). Which shorts are informed? The Journal of Finance, 63(2), 491-527. http://dx.doi.org/10.1111/j.1540-6261.2008.01324.x

Bradley, D., Chan, K., Kim, J., \& Singh, A. (2008). Are there long-run implications of analyst coverage for IPOs? Journal of Banking \& Finance, 32(6), 1120-1132. http://dx.doi.org/10.1016/j.jbankfin.2007.09.021

Bradshaw, M. T., \& Sloan, R. G. (2002). GAAP versus the street: An empirical assessment of two alternative definitions of earnings. Journal of Accounting Research, 40(3), 41-66. http://dx.doi.org/10.1111/1475-679X.00038

Brown, N. C., Wei, K. D., \& Wermers, R. (2009). Analyst recommendations, mutual fund herding, and overreaction in stock prices. Working paper. Retrieved from http://www.rhsmith.umd.edu/finance/pdfs_docs/Symposium2007/AnalyistRecommendations.pdf

Cai, J., \& Zhang, Z. (2011). Leverage change, debt overhang, and stock prices. Journal of Corporate Finance, 17(3), 391-402. http://dx.doi.org/10.1016/j.jcorpfin.2010.12.003

Camerer, C. F. (1989). An experimental test of several generalized utility theories. Journal of Risk and Uncertainty, 2(1), 61-104. http://dx.doi.org/10.1007/BF00055711

Chang, E. C., Cheng, J. W., \& Khorana, A. (2000). An examination of herd behavior in equity market: An international perspective. Journal of Banking \&Finance, 24(10), 1651-1679. http://dx.doi.org/10.1016/S0378-4266(99)00096-5

Chen, S., \& Matsumoto, D. A. (2006). Favorable versus unfavorable recommendations: The impact on analyst access to management-provided information. Journal of Accounting Research, 44, 657-689. http://dx.doi.org/10.1111/j.1475-679X.2006.00217.x

Chiang, T. C., \& Zheng, D. (2010). An empirical analysis of herd behavior in global stock market. Journal of Banking \& Finance, 34(8), 1911-1921. http://dx.doi.org/10.1016/j.jbankfin.2009.12.014

Chou, P. H., Wei, K. C. J., \& Chung, H. (2007). Sources of contrarian profits in the Japanese stock market. Journal of Empirical Finance, 14(3), 261-286. http://dx.doi.org/10.1016/j.jempfin.2006.07.003

Christie, W. G., \& Huang, R. D. (1995). Following the pied piper: Do individual returns herd around the market? Financial Analysts Journal, 51, 31-37. http://dx.doi.org/10.2469/faj.v51.n4.1918

Christophe, S. E., Ferri, M. G., \& Angel, J. J. (2004). Short-selling prior to earnings announcements. Journal of Finance, 59(4), 1845-1876. http://dx.doi.org/10.1111/j.1540-6261.2004.00681.x

Christophe, S. E., Ferri, M. G., \& Hsieh, J. (2010). Informed trading before analyst downgrades: Evidence from short sellers. Journal of Financial Economics, 95(1), 85-106. http://dx.doi.org/10.1016/j.jfineco.2009.02.004

Clarke, J., \& Subramanianb, A. (2006). Dynamic forecasting behavior by analysts: Theory and evidence. Journal of Financial Economics, 80(1), 81-113. http://dx.doi.org/10.1016/j.jfineco.2005.03.008

Clement, M. B., \& Tse, S. Y. (2005). Financial analyst characteristics and herding behavior in forecasting. Journal of Finance, 60(1), 307-341. http://dx.doi.org/10.1111/j.1540-6261.2005.00731.x

Cooper, M., Gulen, H., \& Schill, M. J. (2008). Asset growth and the cross-section of stock returns. Journal of Finance, 63(4), 1609-1651. http://dx.doi.org/10.1111/j.1540-6261.2008.01370.x

Cooper, M., Gutierrez, J. R., \& Hameed, A. (2004). Market states and momentum. Journal of Finance, 59(3), 1345-1365. http://dx.doi.org/10.1111/j.1540-6261.2004.00665.x

Daniel, K., \& Titman, S. (1999). Market efficiency in an irrational world. Financial Analysts Journal, 55(6), 28-40. http://dx.doi.org/10.2469/faj.v55.n6.2312

Dasgupta, A., Prat, A., \& Verardo, M. (2011). Institutional trade persistence and long-term equity returns. Journal of Finance, 66(2), 635-653. http://dx.doi.org/10.1111/j.1540-6261.2010.01644.x

Fama, E. F., \& French, K. R. (1993). Common risk factors in the return on bonds and stocks. Journal of Financial Economics, 33(1), 3-53. http://dx.doi.org/10.1016/0304-405X(93)90023-5

Frankel, R., Kothari, S. P., \& Weber, J. (2006). Determinants of the informativeness of analyst research. Journal of Accounting and Economics, 41(1), 29-54. http://dx.doi.org/10.1016/j.jacceco.2005.10.004

George, T. J., \& Hwang, C. Y. (2010). A resolution of the distress risk and leverage puzzles in the cross section of stock returns. Journal of Financial Economic 96(1), 56-79. http://dx.doi.org/10.1016/j.jfineco.2009.11.003 
Gleason, K. C., Mathur, I., \& Peterson, M. A. (2004). Analysis of intraday herding behavior among the sector ETF. Journal of Empirical Finance, 11(5), 681-694. http://dx.doi.org/10.1016/j.jempfin.2003.06.003

Graham, J. R. (1999). Herding among investment newsletters: Theory and evidence. Journal of Finance, 54(1), 237-268. http://dx.doi.org/10.1111/0022-1082.00103

Gray, P., \& Johnson, J. (2011). The relationship between asset growth and the cross-section of stock returns. Journal of Banking \& Finance, 35(3), 670-680. http://dx.doi.org/10.1016/j.jbankfin.2010.06.005

Grinblatt, M., Titman, S., \& Wermers, R. (1995). Momentum investment strategies, portfolio performance, and herding: A study of mutual fund behavior. American Economic Review, 85(5), 1088-1105.

Hanna, D. (2001). Analysts' earnings forecasts and the recognition of special items. Working paper. Retrieved from http://www.cox.smu.edu/web/douglas-hanna

Hong, H., \& Kubik, J. D. (2003). Analyzing the analysts: Career concerns and biased earnings forecasts. Journal of Finance, 58(1), 313-351. http://dx.doi.org/10.1111/1540-6261.00526

Hong, H., Kubik, J. D., \& Solomon, D. (2000). Security analysts' career concerns and herding of earnings forecasts. The Rand Journal of Economics, 3(1), 121-144. http://dx.doi.org/10.2307/2601032

Huang, D. (2006). Market states and international momentum strategies. The Quarterly Review of Economics and Finance, 46(3), 437-446. http://dx.doi.org/10.1016/j.qref.2004.07.009

Hwang, S., \& Salmon, M. (2004). Market stress and herding. Journal of Empirical Finance, 11(4), 585-616. http://dx.doi.org/10.1016/j.jempfin.2004.04.003

Jegadeesh, N., \& Titman, S. (1993). Returns to buying winners and shelling losers: Implications for stock market efficiency. Journal of Finance, 48(1), 65-91. http://dx.doi.org/10.1111/j.1540-6261.1993.tb04702.x

Jegadeesh, N., Kim, J., Krische, S. D., \& Lee, C. M. C. (2004). Analyzing the analysts: When do recommendations add value? Journal of Finance, 59(3), 1083-1124. http://dx.doi.org/10.1111/j.1540-6261.2004.00657.x

Kim, C., \& Pantzalis, C. (2003). Global/industrial diversification and analyst herding. Financial Analysts Journal, 59(2), 69-79. http://dx.doi.org/10.2469/faj.v59.n2.2515

Kim, M. S., \& Zapatero, F. (2009). Rational bias and herding in analyst' recommendations. Working Papers. Retrieved from http://ssrn.com/abstract=1517571

Lakonishok, J., Shleifer, A., \& Vishny, R. W. (1992). The impact of institutional trading on stock prices. Journal of Financial Economics, 32(1), 23-43. http://dx.doi.org/10.1016/0304-405X(92)90023-Q

Lakonishok, J., Shleifer, A., \& Vishny, R. W. (1994). Contrarian investment, extrapolation, and risk. Journal of Finance, 49(5), 1541-1578. http://dx.doi.org/10.1111/j.1540-6261.1994.tb04772.x

Lakonishok, J., Shleifer, A., Thaler, R., \& Vishny, R. W. (1991). Window dressing by pension fund managers. Working Papers. Retrieved from http://www.nber.org/papers/w3617

Lee, C. M. C., \& Swaminathan, B. (2000). Price momentum and trading volume. Journal of Finance, 55(5), 2017-2069. http://dx.doi.org/10.1111/0022-1082.00280

Li, K., Yue, H., \& Zhao, L. (2009). Ownership, institutions, and capital structure: Evidence from China. Journal of Comparative Economics, 37(3), 471-490. http://dx.doi.org/10.1016/j.jce.2009.07.001

Li, X., \& Sullivan, R. N. (2011). The limits to arbitrage revisited: The accrual and asset growth anomalies. Financial Analysts Journal, 67(4), 50-66. http://dx.doi.org/10.2469/faj.v67.n4.5

Lin, H. W., \& McNichols, M. F. (1998). Underwriting relationships, analysts' earnings forecasts and investment recommendations. Journal of Accounting and Economics, 25(1), 101-128. http://dx.doi.org/10.1016/S0165-4101(98)00016-0

Lin, W. Y., Chen, P. J., \& Chen, S. S. (2011). Stock characteristics and herding in financial analyst $\begin{array}{llll}\text { recommendations. } & \text { Applied }\end{array}$ http://dx.doi.org/10.1080/09603107.2010.528367

Michaely, R., \& Womack, K. L. (1999). Conflict of interest and the credibility of underwriter analyst recommendations. Review of Financial Studies, 12(4), 653-686. http://dx.doi.org/10.1093/rfs/12.4.653

Myer, S. C. (1977). Determinants of corporate borrowing. Journal of Financial Economics, 5(2), 147-176. http://dx.doi.org/10.1016/0304-405X(77)90015-0 
Naujoks, M., Aretz, K., Kerl, A., \& Walter, A. (2007). Do German security analysts herd? Financial Markets and Portfolio Management, 23(1), 3-29. http://dx.doi.org/10.1007/s11408-008-0093-7

O’Brien, P. C., McNichols, M. F., \& Lin, H. W. (2005). Analyst impartiality and investment banking relationships. Journal of Accounting Research, 43(4), 623-650. http://dx.doi.org/10.1111/j.1475-679X.2005.00184.x

Prendergast, C., \& Stole, L. (1996). Impetuous youngsters and jaded old-timers: Acquiring a reputation for learning. Journal of Political Economy, 104(6), 1105-1134. http://dx.doi.org/10.1086/262055

Rau, P. R., \& Vcrmaelen, T. (1998). Glamour, value and the post-acquisition performance of acquiring firms. Journal of Financial Economic, 49(2), 223-253. http://dx.doi.org/10.1016/S0304-405X(98)00023-3

Scharfstein, D., \& Stein, J. (1990). Herd behavior and investment. The American Economic Review, 80(3), 465-479.

Shefrin, H., \& Statman, M. (1985). The disposition to sell winners too early and ride losers too long: Theory and evidence. Journal of Finance, 40(3), 777-790. http://dx.doi.org/10.1111/j.1540-6261.1985.tb05002.x

$\mathrm{Su}, \mathrm{D}$. (2004). Leverage, insider ownership, and the underpricing of IPOs in China. Journal of International $\begin{array}{lllll}\text { Financial Markets, } \quad \text { Institutions } & \text { Money, } & \text { 14(1), } & \text { 37-54. }\end{array}$ http://dx.doi.org/10.1016/S1042-4431(03)00043-X

Trueman, B. (1994). Analyst forecasts and herding behavior. Review of Financial Studies, 7(1), 97-124. http://dx.doi.org/10.1093/rfs/7.1.97

Wang, Z., Chang, Z., \& Liu, L. (2006). Whether analysts' recommendations have investment value: Empirical data from the Chinese market. Research on Financial and Economic, 7, 36-44. (in Chinese)

Wei, Z., \& Varela, O. (2003). State equity ownership and firm market performance: Evidence from China's newly privatized firms. Global Finance Journal, 14(1), 65-82. http://dx.doi.org/10.1016/S1044-0283(03)00005-X

Welch, I. (1992). Sequential sales, learning, and cascades. Journal of Finance, 47(2), 695-732. http://dx.doi.org/10.1111/j.1540-6261.1992.tb04406.x

Welch, I. (2000). Herding among security analysts. Journal of Financial Economics, 58(3), 369-396. http://dx.doi.org/10.1016/S0304-405X(00)00076-3

Wermers, R. (1999). Mutual fund herding and the impact on stock prices. Journal of Finance, 54(2), 581-622. http://dx.doi.org/10.1111/0022-1082.00118

Womack, K. L. (1996). Do brokerage analysts' recommendations have investment value? Journal of Finance, 51(1), 137-167. http://dx.doi.org/10.1111/j.1540-6261.1996.tb05205.x

Yu, F. (2008). Analyst coverage and earnings management. Journal of Financial Economics, 88(2), 245-271. http://dx.doi.org/10.1016/j.jfineco.2007.05.008

Zitzewitz, E. (2001). Measuring herding and exaggeration by equity analyst and other opinion sellers. Working paper. Retrieved from http://dx.doi.org/10.2139/ssrn.405441

Notes

Note $1 . \quad$ The report is available http://finance.sina.com.cn/stock/quanshang/ybyj/20121206/235413923917.shtml

Note 2. After establishing the Shanghai Stock Exchange in 1990, China's government was concerned about losing its control on state-owned enterprises. The "Split Share Structure" program was enacted to divide ownership into tradable and non-tradable shares. Tradable shares were offered to the public and were traded freely in stock exchanges, whereas non-tradable shares were held by original shareholders or the government and were not allowed to be traded. This program was deregulated on April 29, 2005 by the China Securities Regulatory Commission by enacting the "Notice of Issues Concerning the Trial Reform of Split Share Structure of Listed Companies," also known as the "Split Share Reform." Non-tradable shares were allowed to be traded publicly by paying "compensations" to shareholders who owned tradable stocks. Because outstanding shares of public enterprises were rare during the data collection duration, this study uses a firm's total asset as a proxy for firm size instead of market capitalization.

Note 3. Bradshaw and Sloan (2002) defined "street earnings" as "the numbers announced by corporations in their press releases and tracked by analyst estimate clearinghouse services, such as I/B/E/S, Zacks, and First 
Call."

Note 4. The report is available at: http://finance.sina.com.cn/stock/stocktalk/20121207/015113925357.shtml 